\title{
Symmetrical peripheral gangrene
}

\author{
Amr Ismail MD, Audra Schwalk MD
}

\section{INTRODUCTION AND DEFINITION}

Symmetrical peripheral gangrene (SPG) was first described in the British Journal in 1891. ${ }^{1}$ Symmetrical peripheral gangrene is sudden onset acral, often symmetrical, gangrene with no signs of major vascular occlusive disease. ${ }^{2,3,4}$ Symmetrical peripheral gangrene is sometimes referred to as purpura fulminans $(\mathrm{PF})$, although in contrast, PF can also cause non-acral tissue necrosis. ${ }^{3}$ Patients may have pallor, cyanosis, severe pain or cool extremities on physical examination; arterial pulses are usually detectable even late in the disease. ${ }^{3}$ It is commonly reported to affect distal lower extremities more often than upper extremities, but in rare conditions, ears, nose, lips, and scalp have also been involved. ${ }^{4}$ Patients with this condition have increased mortality when compared to critically ill patients without SPG and a high risk of limb amputations in those fortunate enough to survive. ${ }^{3}$ Symmetrical peripheral gangrene has sporadically been reported in the literature for over a century, but cases are increasingly being recognized in critically ill patients, necessitating improved awareness for this condition.

\section{ETIOLOGY, PATHOGENESIS, AND HISTOPATHOLOGY}

The proposed etiology of SPG has evolved significantly over the years, and its occurrence is likely multifactorial. Most early reported cases were thought to be secondary to embolic phenomena, but more recently published cases provide alternative methods of injury. In the late 1900s, SPG was thought to be due

\footnotetext{
Corresponding author: Amr Ismail Contact Information: Amr.ismail@ttuhsc.edu DOI: 10.12746/swrccc.v7i28.537
}

to vasospastic conditions, small vessel obstruction, and conditions associated with very low cardiac output. ${ }^{5}$ Case reports of SPG in patients with septic shock on vasopressors then started to emerge, providing evidence that SPG may be a side effect of vasopressors alone. This was later refuted by the occurrence of SPG in patients on very minimal doses of vasopressors or even in patients not requiring vasopressors. ${ }^{4}$ The underlying causes of SPG are often now divided into infectious (bacterial, parasitic or viral) and non-infectious etiologies (Table 1). ${ }^{3}$ Meningococcemia is the most commonly recognized infectious process associated with SPG and PF in children, whereas Streptococcus pneumoniae is most common in adults. ${ }^{4}$

Most published case reports now recognize a strong association between DIC and SPG, and it is believed that DIC is the common pathway of the different etiologies. Lab findings, especially late in the disease, are typically consistent with DIC. Thrombocytopenia is often seen first, followed by an elevated D-dimer and INR, low protein $\mathrm{C}$ level, and schistocytes on peripheral blood smear. ${ }^{3}$ Recent publications have also reported that acute ischemic hepatitis, or shock liver, occurs in approximately $90 \%$ of critically ill patients with DIC that later develop SPG. ${ }^{4}$ A skin biopsy provides confirmation of SPG, but this diagnosis can usually be made with clinical criteria. ${ }^{3}$ Research shows early petechial skin lesions are caused by edematous endothelial cells, capillary dilatation, and red-cell extravasation. ${ }^{4}$ These petechial lesions coalesce over time to form hemorrhagic bullae in regions of ischemic necrosis., ${ }^{3,4}$ On histopathological examination, microvascular thrombosis of capillaries with fibrin deposition and red cell extravasation are visualized, but vasculitis and inflammatory cells in the vessel walls are not typically seen. ${ }^{3,4}$ Rarely, SPG can occur in the absence of DIC with a variety of conditions being described in the literature. ${ }^{4}$ Although this condition is being reported with increased frequency, it is still considered rare and not well understood. 
Table 1. Etiology of symmetrical peripheral gangrene

\begin{tabular}{|c|c|}
\hline Infectious Causes & Non-infectious Causes \\
\hline $\begin{array}{l}\text { Bacterial } \\
\text { - Neisseria meningitidis } \\
\text { - Streptococcus } \\
\text { pneumoniae } \\
\text { - Staphylococcus aureus } \\
\text { - Streptococcus pyogenes } \\
\text { - Klebsiella pneumoniae } \\
\text { - Salmonella paratyphi } \\
\text { - Proteus sp. } \\
\text { - Enterococcus faecalis } \\
\text { - Escherichia coli }\end{array}$ & $\begin{array}{l}\text { Cardiovascular } \\
\text { - Myocardial infarction } \\
\text { - Heart failure } \\
\text { - Supraventricular } \\
\text { tachycardia } \\
\text { - Pulmonary embolism }\end{array}$ \\
\hline $\begin{array}{l}\text { Viral } \\
\text { - HIV } \\
\text { - Varicella zoster } \\
\text { - Rubeola } \\
\text { - Dengue fever } \\
\end{array}$ & $\begin{array}{l}\text { Drugs } \\
\text { - Epinephrine } \\
\text { - Norepinephrine } \\
\text { - Dopamine }\end{array}$ \\
\hline \multirow[t]{4}{*}{$\begin{array}{l}\text { Parasitic } \\
\text { - Plasmodium falciparum }\end{array}$} & $\begin{array}{l}\text { Malignancy } \\
\text { - Lung adenocarcinoma } \\
\text { - Adenocarcinoma } \\
\text { associated thrombotic } \\
\text { endocarditis } \\
\text { - Hodgkin's lymphoma }\end{array}$ \\
\hline & $\begin{array}{l}\text { Connective Tissue } \\
\text { Disease } \\
\text { - Systemic Lupus } \\
\text { Erythematosus } \\
\text { - Antiphospholipid } \\
\text { syndrome } \\
\text { - Polymyalgia } \\
\text { rheumatica }\end{array}$ \\
\hline & $\begin{array}{l}\text { Miscellaneous } \\
\text { - Protein C and protein } \\
\text { S deficiency } \\
\text { - Sickle cell disease } \\
\text { - Cryoglobulinemia }\end{array}$ \\
\hline & Idiopathic \\
\hline
\end{tabular}

(Table adapted from Management of Symmetrical Peripheral Gangrene ${ }^{3}$ )

\section{Clinical course and treatment}

Due to the rarity of the condition and limited prospective and retrospective studies, there is no consensus about the treatment. Underlying DIC needs to be managed promptly and appropriately. In cases where bleeding is predominant, replacement of coagulation factors is essential. This can be achieved with transfusion of specific factor concentrates, fresh frozen plasma or platelets. ${ }^{4}$ If thrombosis is the presenting symptom, several anticoagulants are now available for treatment. Low dose heparin (300-500 IU/hour) is the most well-studied medication in cases of DIC and may stop the progression of mild ischemia to frank gangrene, but no medication has been shown to definitively improve mortality in DIC. ${ }^{3}$ A recently published meta-analysis suggested that heparin use in patients with septic shock and infection related DIC may be associated with decreased mortality rate, but this has yet to be confirmed in other studies. ${ }^{4}$

The main treatment goal of SPG is to stop or at least slow progression of the disease. This is primarily achieved by treatment of the underlying cause, removal of contributing medications and prevention of secondary bacterial infections. ${ }^{3}$ Extremity compartment pressures should be monitored closely and fasciotomy can be performed as needed for treatment of compartment syndrome. ${ }^{6}$ Removal of non-viable tissues may also be necessary in this condition, ${ }^{3}$ although this should be completed with caution as it may be difficult to distinguish viable from non-viable tissue early in the disease. ${ }^{4}$ As Warkentin said, "patience to the point of autoamputation" may be the best approach in many cases of SPG in order to preserve tissue. ${ }^{6}$

Several additional therapies, including hyperbaric oxygen, ${ }^{7}$ trimethaphan, ${ }^{8}$ and sodium nitroprusside, ${ }^{9}$ among others, have been reported in individual case studies, but none of these treatment modalities have proven benefit.

\section{Conclusion}

Symmetrical peripheral gangrene is a rare disorder that usually occurs in critically ill patients, primarily with cardiogenic or septic shock. ${ }^{4}$ The reported mortality rate associated with SPG is quite high, with studies reporting ranges of $18-90 \% .{ }^{3}$ As increased awareness for this condition develops and as improved outcomes are seen in patients with septic shock, patients may 
be faced with the lifelong effects of this disorder with many living as amputees. It is imperative that critical care practitioners maintain a high level of suspicion for this diagnosis as early recognition and treatment is crucial to survival.

Keywords: gangrene, peripheral, disseminated intravascular coagulation, sepsis

Article citation: Ismail A, Schwalk A. Symmetrical peripheral gangrene. The Southwest Respiratory and Critical Care chronicles 2019;7(28):4-6

From: The Department of Internal Medicine at Texas Tech University Health Sciences Center in Lubbock, Texas

Submitted: $3 / 29 / 2019$

Accepted: 4/4/2019

Conflicts of interest: none

This work is licensed under a Creative Commons Attribution-ShareAlike 4.0 International License.

\section{REFERENCES}

1. Hutchinson J. Severe symmetrical gangrene of the extremities. BMJ 1891;2:8-9.

2. Davis MDP. Peripheral symmetrical gangrene. Mayo Clin Proc 2004 Jul;79(7):914.

3. Foead AI. Management of symmetrical peripheral gangrene. Indian J Crit Care Med 2018 Dec;22(12):870-874.

4. Warkentin TE. Ischemic limb gangrene with pulses. N Engl J Med 2015;373:642-55.

5. McGouran RCM. Symmetrical peripheral gangrene. British Heart J 1977 May;39(5):569-572.

6. Fagan S, Spies M, Hollyoak M, et al. Exfoliative and necrotizing diseases of the skin. Total Burn Care, edited by David N. Herndon. Elsevier; 2007. p. 554-65.

7. Stewart S. Symmetrical peripheral gangrene and the use of systemic hyperbaric oxygen therapy. J Wound Care 2012;21: 615-6,618-9.

8. Ghosh SK, Bandyopadhyay D. Symmetrical peripheral gangrene. Indian J Dermatol Venereol Leprol 2011;77:244-8.

9. Joynt G, Doedens L, Lipman J, et al. High-dose adrenaline with low systemic vascular resistance and symmetrical peripheral gangrene. S Afr J Surg 1996;34:99-101. 